\title{
Ecological and Taxonomical Perspective of Yeasts in Indonesia
}

\author{
WELLYZAR SJAMSURIDZAL ${ }^{1 *}$, ARIYANTI OETARI ${ }^{1}$, ATIT KANTI ${ }^{2}$, RASTI SARASWATI ${ }^{3}$, \\ CHIHARU NAKASHIMA ${ }^{4}$, YANTYATI WIDYASTUTI $^{5}$, AND ANDO KATSUHIKO ${ }^{6}$
}

\author{
${ }^{\prime}$ Department of Biology, Faculty of Mathematics and Natural Sciences, Universitas Indonesia, UI Campus, Depok 16424, \\ Indonesia; ${ }^{2}$ Research Center for Biology, Lembaga Ilmu Pengetahuan Indonesia, Jalan Raya Jakarta-Bogor Km.46 \\ Cibinong, Bogor 16911, Indonesia; ${ }^{3}$ Soil Biology and Health Division Indonesian Soil Research Institute, Departemen \\ Pertanian, Jalan Tentara Pelajar, Bogor, 16111 Indonesia, ${ }^{4}$ Faculty of Bioresources, Mie University, 1577 Kurima- \\ Machiya Tsu, Mie 514-8507, Japan; ${ }^{5}$ Research Center for Biotechnology, Lembaga Ilmu Pengetahuan Indonesia, \\ Jalan Raya Jakarta-Bogor Km 46 Cibinong, Bogor 16911, Indonesia $;{ }^{6}$ Department of Biotechnology, \\ National Institute of Technology Evaluation, 1-1-1, Fugiwara-Cho, Kisarazu, Chiba 292-1234, Japan
}

\begin{abstract}
In the course of ecological and taxonomical study of yeasts in Indonesia, a total of 2147 yeast isolates from 315 samples in the year 2003 , 2005, 2006 and 2008 had been obtained from eight locations e.g. Liwa (Sumatera), Cibinong (Java), Cibodas (Java), Kutai (Kalimantan), Enrekang (Sulawesi), Pucak (Sulawesi), Gili and Kuta (Lombok), and Kupang (Timor). Leaves, flowers, litters, soils, epiphytic soils, insects and insect's nests were collected for yeasts isolation. Our molecular identification based on D1/D2 region of nuclear large-subunit rDNA and the internal transcribed spacer (ITS) regions sequence data on 525 representative isolates revealed that 306 isolates belong to 48 described species (18 genera) and 209 strains belong to 19 undescribed species (19 genera), and 10 isolates were discarded because of contamination. Based on their substrates, litter had the highest yeasts genera (19) followed by soils (18), flowers (10), leaves (6), epiphytic soils (4), and insects and insect's nests (4). Genera found on soils were also common on litters. Yeasts genera found on flowers and epiphytic soils were common on leaves and litters. The genera Aureobasidium, Cryptococcus, Pseudozyma, Rhodotorula and Sporidiobolus were found in all substrates. Based on their locations, Kutai had the highest number of genera (15) followed by Cibodas (10), Cibinong (10), Enrekang (10), Kupang (10), Pucak (9), Liwa (7) and Lombok (7). The genus Cryptococcus was found in all locations. Our study shed a light to detection of many new taxa of yeasts, $41 \%$ of yeasts found in this study represented novel taxa.
\end{abstract}

Key words: yeasts, diversity, Indonesia, D1/D2 of LSU rDNA, ITS regions

Tropical fungi are a major component of biodiversity essential to the survival of other organisms, crucial in global ecological processes, a source of novel bioactive compounds, a source of biocontrol agents, a source of plant pathogens, a threat to human health, and able to contribute to sustainable development and a part of human culture (Hawksworth 2002). It is estimated that 1.5 million species of fungi exist in the world (Hawksworth 1991), however, up to now only $10 \%$ of those number have been described. More than $50 \%$ of fungal diversity is expected to be found in tropical regions. The studies from the viewpoint of biodiversity in Asia have just started and further extensive studies are required (Nakase et al. 2006). Indonesia as a tropical country has a large area and rich in variety of habitats to be explored for its fungal diversity. Various habitats in Indonesia are under-explored microbial ecosystems and are threatened for biodiversity loss. Alikodra and Syaukani (2004) reported that the rate of deforestation in Indonesia was the highest in the world and reached 3.8 million ha per year. Tropical deforestation causes habitat loss and its accompanying fungal loss will include some species which may have the ability to produce important but yet undiscovered chemical molecules. To date, there is very little information on species diversity of Indonesian indigenous yeasts and yeast-like fungi.

In Indonesia, like other South-East Asian countries, yeast research has been started in the early stage of microbial studies of traditional fermented products, foods, beverages and starters of fermentation (Nakase et al. 2006). The study of yeasts from natural environments in Indonesia started some 40 years ago when Deinema in 1961 found Candida

*Corresponding author, Phone: +62-21-78884762; Fax: +62-21-7270012; Email: sjwelly@hotmail.com bogoriensis from the surface of leaves of the flowering shrubs Randia melleifera (Rubiaceae) in Bogor. In the last decade, many studies have been conducted to investigate yeasts biodiversity from natural environment of Indonesia, however most of the identification were based on conventional methods (Sjamsuridzal and Gandjar 1994; Oetari et al. 1999; Sudiana and Rahmansyah 2002). Information on yeasts diversity based on molecular method from natural environment in Indonesia appeared in the year 1999 as reported by Haryono et al. (1999), they informed the basidiomycetous yeasts isolated from the suburb of Yogyakarta; then Sjamsuridzal et al. (2003) reported yeasts from Pulau Rambut, Muara Angke and marine of Teluk Jakarta. Based on their studies, yeasts biodiversity in the natural environment of Indonesia was predicted to be rich. Their report indicated that more novel yeasts species living in natural environment of Indonesia are waiting to discover.

In this study, we investigated yeasts isolated from various sources in environment in Indonesia based on the phylogenetic analysis of D1/D2 region of LSU rDNA and ITS regions.

\section{MATERIALS AND METHODS}

Sampling Locations. Samplings were conducted in the year 2003, 2005, 2006, and 2008 and we sampled several substrates e.g., living plants (leaves, flowers), litters, soils, epiphytic, insects (arthropods), and insect's nests. Collection of samples was conducted in Cibodas Botanical Garden, West Java in the year 2003; Kupang (Nusa Tenggara Timur), Enrekang (South Sulawesi) and Cibinong (West Java) in the year 2005; Kutai (East Kalimantan), Gili and Kuta (Lombok Island), and Cibinong (West Java) in the year 2006; and Pucak Botanical Garden (South Sulawesi), and Liwa 
Botanical Garden (Lampung, South Sumatera) in the year 2008 (Fig 1). The number of samples collected at eight sampling sites in Indonesia in 2003, 2005, 2006, and 2008 can be seen in Table 1 .

Isolation of Yeasts. Several kinds of sample materials, e.g., leaves, flowers, litters, epiphytic soils, insects, and insect's nests, were collected from various parts of Indonesia. Each of sample materials was used for the isolation of yeasts and yeast-like fungi. Methods for isolation, maintenance, and preservation were carried out based on Yarrow (1998). Yeasts were isolated by dilution, direct inoculation, membrane filtration, particle filtration, walk over plate (for insects), ballistospore fall-method, UV treatment and heat shock treatment.

DNA Preparation. The cultures were cultivated in YM broth ( $3 \mathrm{~g}$ yeasts extract, $3 \mathrm{~g}$ malt extract, $5 \mathrm{~g}$ polypeptone, $10 \mathrm{~g}$ glucose, $1 \mathrm{~L}$ distilled water), and the cells were harvested during the logarithmic phase of growth and collected by centrifugation. The DNA was extracted and purified by using the method of Sjamsuridzal and Oetari (2003), or by using DNeasy Plant Tissue Kit (QIAGEN).

Amplification of D1/D2 of LSU rDNA and ITS Regions by PCR. The D1/D2 region of nuclear large subunit ribosomal DNA and the ITS regions were amplified and sequenced using the primer sets, NL1 (GCATATCAATAA GCGGAGGAAAAG) and NL 4 (GGTCCGTGTTCAAG ACGG), and ITS4 (TCCTCCGCTTATTGATATGC) and ITS5 (GGAAGTAAAAGTCGTAACAAGG), respectively, as described by White et al. (1990).

Sequencing of D1/D2 of LSU rDNA and ITS Regions. The nucleotide sequences were determined with Big Dye Terminator v3.1 Cycle Sequencing Ready Reaction Kit (Applied Biosystems) following the manufacturer's instructions. The gel electrophoresis and data collection were performed on ABI Prism Genetic Analyzer (Applied Biosystems). The sequence of D1/D2 region of LSU rDNA

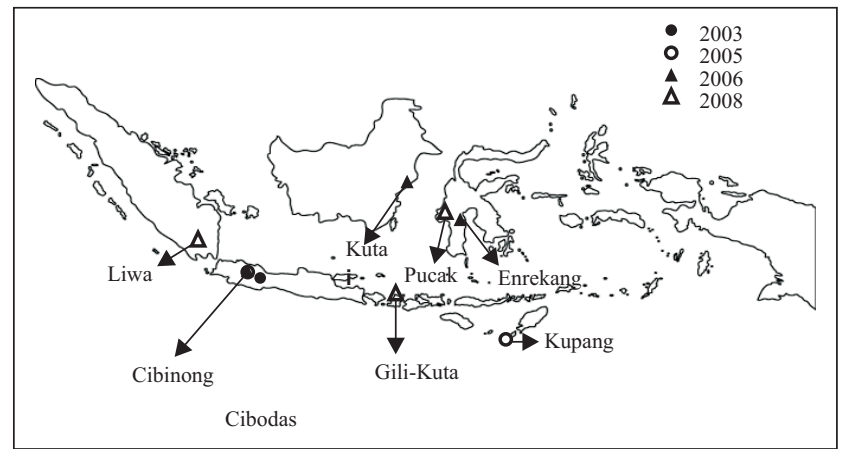

Fig 1 Map of sampling sites in Indonesia.

Table 1 Number of samples and isolates obtained from each year collection

\begin{tabular}{cccc}
\hline Year & $\begin{array}{c}\text { Number of } \\
\text { samples }\end{array}$ & $\begin{array}{c}\text { Number of } \\
\text { isolated yeasts }\end{array}$ & $\begin{array}{c}\text { Number of representative } \\
\text { isolates }\end{array}$ \\
\hline 2003 & 41 & 1029 & 75 \\
2005 & 144 & 549 & 250 \\
2006 & 77 & 344 & 100 \\
2008 & 53 & 225 & 100 \\
\hline Total & 315 & 2147 & 525 \\
\hline
\end{tabular}

and ITS regions of the strains were aligned with other LSU rDNA sequences on the basis of similarity of the sequences. Yeast isolates were identified by the $99 \%$ similarity criteria of D1/D2 region of LSU rDNA (Kurtzman and Robnett 1998 ) or by at least $1 \%$ sequence diversity of ITS regions (Sugita et al. 1999; Caligiorne et al. 2005).

Phylogenetic Analysis. The sequences data were sent to online international DNA database for homology search by Basic Local Algorithm Search Tools (BLAST) (Altschul et al. 1997). Sequences were aligned using CLUSTALX (Thompson et al. 1994) and were adjusted manually. The gaps were not included in our phylogenetic analyses. The distance matrix for the aligned sequences was calculated using the two-parameter method of Kimura (1980). The neighbor-joining (NJ) method (Saitou and Nei 1987) was used to construct all phylogenetic trees. The robustness for individual branches was estimated by bootstrapping (Felsenstein 1985) with 1000 resamplings.

Preservation of Yeast Cultures. The preservation of yeasts isolates were conducted by two methods, e.g., preservation in $10 \%$ glycerol solution (in $-80^{\circ} \mathrm{C}$ ), each isolates preserved in 3 cryogenic tubes; and preservation by liquid drying lyophilization, five ampoules were prepared for each isolates. Yeasts were preserved in University of Indonesia Culture Collection (UICC) and LIPI Microbial Culture Collection (LIPIMCC), Indonesia, and one copy of representative isolates were deposited at the Department of Biotechnology National Institute of Technology Evaluation (DOB NITE), Japan.

\section{RESULTS}

Isolation of Yeasts and Yeast-Like Fungi in Indonesia. We sampled various natural habitats including leaves, flowers, litter, soil, epiphytic soil, and insects and insect's nests. As a total of 2147 isolates (Table 1) were obtained from 315 of samples in four years from eight sampling locations in Java, Kalimantan, Lombok, Sulawesi, Sumatera, and Timor (Fig 1), we selected 525 representative isolates for molecular identification (Tables 1 and 2). Table 3 showed that a total of 133 representative yeasts isolates were selected from 115 soil samples. Table 4 showed that a total of 276 isolates were selected from 95 litter samples. Table 5 showed that a total of 52 isolates were selected from 21 flower samples; 12 isolates were selected from 12 pollen samples; 22 isolates were selected from 20 leaves samples; 21 isolates from 11 epiphytic soil; and 9 isolates from 41 insects and insect's nest samples.

Yeasts and Yeast-Like Fungi Found from Natural Environment of Indonesia. We selected 525 from a total 2147 isolates as representative isolates for molecular identification. From those selected isolates, we had sequenced 515 isolates and 10 isolates were discarded because of contamination. Our molecular identification based on D1/D2 region of nuclear large-subunit rDNA and the internal transcribed spacer (ITS) regions sequence data revealed that 306 isolates belong to 48 described species (18 genera) and 209 strains belong to 19 undescribed species 
Table 2 Number of samples collected at nine sampling sites in Indonesia

\begin{tabular}{lllc}
\hline Year & Sampling site & Location & $\begin{array}{c}\text { Number of } \\
\text { samples }\end{array}$ \\
\hline 2003 & Cibodas & West Java & 41 \\
& Kupang & West Timor & 53 \\
2005 & Enrekang & South Sulawesi & 67 \\
& Cibinong & West Java & 24 \\
& Kutai & East Kalimantan & 35 \\
2006 & Gili and Kuta & Lombok Island & 15 \\
& Cibinong & West Java & 27 \\
& Pucak & South Sulawesi & 29 \\
& Liwa & South Sumatera & 24 \\
\hline
\end{tabular}

Table 3 Number of yeasts and yeast-like fungi cultures isolated from soil samples collected at seven sampling sites in Indonesia

\begin{tabular}{llcc}
\hline Sampling Site & \multicolumn{1}{c}{ Location } & $\begin{array}{c}\text { Number of } \\
\text { samples }\end{array}$ & $\begin{array}{c}\text { Number of } \\
\text { cultures }\end{array}$ \\
\hline Kupang & West Timor & 20 & 7 \\
Enrekang & South Sulawesi & 24 & 16 \\
Cibinong & West Java & 6 & 7 \\
Kutai & East Kalimantan & 15 & 24 \\
Gili and Kuta & Lombok Island & 14 & 15 \\
Cibinong & West Java & 7 & 9 \\
Pucak & South Sulawesi & 16 & 25 \\
Liwa & South Sumatera & 13 & 30 \\
\hline \multicolumn{2}{r}{} & 115 & 133 \\
\hline
\end{tabular}

Table 4 Number of yeasts and yeast-like fungi cultures isolated from litter samples collected at several sampling sites in Indonesia

\begin{tabular}{cllcc}
\hline \multirow{2}{*}{ Year } & $\begin{array}{c}\text { Sampling } \\
\text { Site }\end{array}$ & Location & $\begin{array}{c}\text { Number of } \\
\text { Samples }\end{array}$ & $\begin{array}{c}\text { Number of } \\
\text { Cultures }\end{array}$ \\
\hline \multirow{2}{*}{2005} & Kupang & West Timor & 20 & 116 \\
& Enrekang & South Sulawesi & 25 & 74 \\
& Kutai & East Kalimantan & 20 & 31 \\
\multirow{2}{*}{2006} & Gili-Kuta & Lombok & 1 & 10 \\
& Cibinong & West Java & 5 & 0 \\
& Pucak & South Sulawesi & 13 & 25 \\
& Liwa & South Sumatera & 11 & 20 \\
\hline \multirow{2}{*}{ Total } & & 95 & 276 \\
\hline
\end{tabular}

Table 5 Number of yeasts and yeast-like fungi cultures isolated from other samples collected at several sampling sites in Indonesia

\begin{tabular}{cllcc}
\hline Year & $\begin{array}{l}\text { Sampling } \\
\text { Site, } \\
\text { Location }\end{array}$ & Sample & $\begin{array}{c}\text { Number } \\
\text { of } \\
\text { Samples }\end{array}$ & $\begin{array}{c}\text { Number } \\
\text { of } \\
\text { Cultures }\end{array}$ \\
\hline 2003 & Cibodas & Flower & 17 & 41 \\
& & Pollen & 12 & 12 \\
2005 & Kupang, & Insects & 12 & 22 \\
& West Timor & (arthropods), & 11 & 4 \\
& Enrekang, & Epiphytic soil & 2 & 4 \\
& South Sulawesi & (arthropods) & 15 & 3 \\
& Cibinong & Epiphytic soil & 3 & 4 \\
& West Java & (nsects & 15 & 2 \\
& (arthropods), & 15 & 13 \\
& Cibinong & Epiphytic soil & 3 & 11 \\
& West Java & Llower & 4 & 0 \\
\hline & Teaves & 8 & 116 \\
\hline
\end{tabular}

(19 genera). The yeasts species found in this study were shown in Table 6.
Diversity and Distribution of Yeasts and Yeast-Like Fungi at Different Sampling Locations. Table 6 showed the occurrence of the species of yeasts and yeast-like fungi at different sampling sites. Based on their locations, Kutai (Kalimantan) had the highest number of genera (15) followed by Cibodas (10), Cibinong (10), Enrekang (10), Kupang (10), Pucak (9), Liwa (7), and Lombok (7). The genus Cryptococcus was found in all locations.

Diversity and Distribution of Yeasts and Yeast-Like Fungi on Various Substrates. As shown in Table 7, in this study, we found 10 genera of yeasts from 21 flower samples, 6 genera of yeasts from 12 pollen samples, 5 genera from 11 epiphytic soil samples, and 4 genera from 41 insects and insect's nest samples. We found 19 genera of yeasts isolated from 95 litter samples, 18 genera of yeasts from 115 soil samples, and 6 genera from 20 leaf samples (Table 7).

Phylogenetic Placements of Yeasts from Indonesia and Detection of Novel Taxa. Phylogenetic analysis based on D1/D2 of rDNA sequence data showed the phylogenetic placements of interesting yeast isolates within the major classes of the phyla Ascomycota and Basidiomycota. The phylogenetic placements of new taxa within the class Euascomycetes which were obtained in Indonesia can be seen in Fig 2; some novel yeasts species within Metschnikowiaceae lineage in the class Hemiascomycetes can be seen in Fig 3; other novel yeast taxa within other lineages in the class Hemiascomycetes can be seen in Fig 4; novel yeasts taxa within the class Urediniomycetes can be seen in Fig 5; novel yeasts taxa in the class Ustilaginomycetes can be seen in Fig 6; and some undescribed Cystofilobasidium species in the class Hymenomycetes which were obtained in Indonesia can be seen in Fig 7.

\section{DISCUSSION}

Our molecular identification based on D1/D2 region of nuclear large-subunit rDNA and the internal transcribed spacer (ITS) regions sequence data on 525 representative isolates revealed that 306 isolates belong to 48 described species (18 genera) and 209 isolates belong to 19 undescribed species (19 genera). Our molecular analysis revealed that those yeast isolates are phylogenetically diverse and distributed in the two major classes of the phylum Ascomycota (i.e. Hemiascomycetes and Euascomycetes) and in three major classes of the phylum Basidiomycota (i.e. Urediniomycetes, Hymenomycetes, and Ustilaginomycetes) (Figs 2-7). Many genera and species found in this study, such as Anomalomyces, Cystofilobasidium bisporidii, C. capitatum, C. ferigula, Dothichiza, Kabatiella, Kodamaea ohmeri, Lecythophora, Spathaspora, and Tetrapisispora had never been reported from Indonesia.

In this study, the yeast Sporidiobolus ruineniae var. ruineniae was found in all sampling locations except in Kutai (Kalimantan) and Lombok (Table 6). This species seems to be a tropical yeast because only found in tropical 
Table 6 Occurrence of the species of yeasts and yeast-like fungi at different sampling sites. Location: $\mathrm{A}=$ Cibodas (West Java); $\mathrm{B}=$ Cibinong (West Java); $\mathrm{C}=$ Kupang (West Timor); $\mathrm{D}=$ Enrekang (South Sulawesi); E= Kutai (East Kalimantan); $F=$ Lombok (Lombok Island); $G=$ Pucak (South Sulawesi); H=Liwa (Lampung).

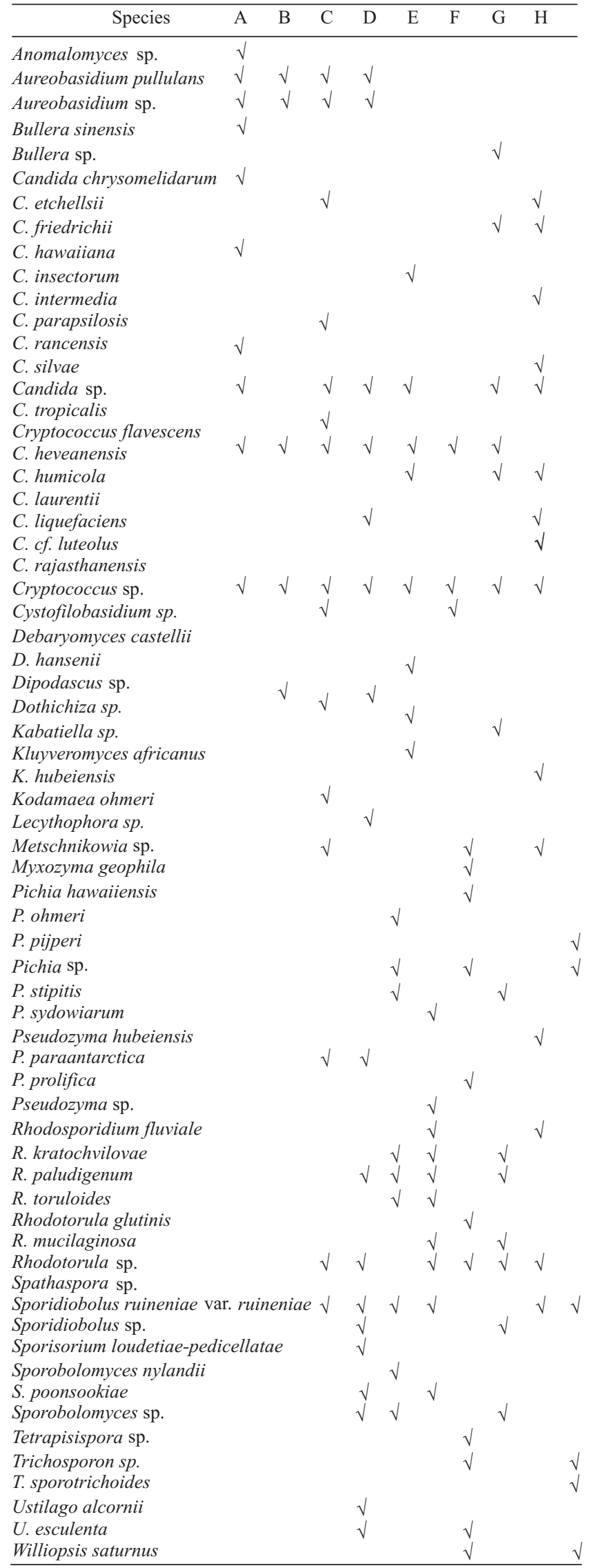

Table 7 Occurrence of the genera of yeasts and yeast-like fungi on different substrates. Substrates: 1, soil; 2, litter; 3, flower; 4, pollen; 5, leaves; 6 , epiphytic soil; 7, insect

\begin{tabular}{|c|c|c|c|c|c|c|c|}
\hline Genus & 1 & 2 & 3 & 4 & 5 & 6 & 7 \\
\hline Anomalomyces & & & $\sqrt{ }$ & & & & \\
\hline Aureobasidium & $\sqrt{ }$ & $\sqrt{ }$ & $\sqrt{ }$ & $\sqrt{ }$ & $\sqrt{ }$ & $\sqrt{ }$ & \\
\hline Bullera & $\sqrt{ }$ & & $\sqrt{ }$ & & & & \\
\hline Candida & $\sqrt{ }$ & $\sqrt{ }$ & $\sqrt{ }$ & $\sqrt{ }$ & & & $\sqrt{ }$ \\
\hline Cryptococcus & $\sqrt{ }$ & $\sqrt{ }$ & $\sqrt{ }$ & $\sqrt{ }$ & $\sqrt{ }$ & & $\sqrt{ }$ \\
\hline Cystofilobasidium & $\sqrt{ }$ & $\sqrt{ }$ & & & & & \\
\hline Debaryomyces & & $\sqrt{ }$ & & & & $\sqrt{ }$ & \\
\hline Dipodascus & $\sqrt{ }$ & & & & & & \\
\hline Dothichiza & & $\sqrt{ }$ & & & & & \\
\hline Kabatiella & & $\sqrt{ }$ & & & & & \\
\hline Kluyveromyces & $\sqrt{ }$ & & & & & & \\
\hline Kodamaea & $\sqrt{ }$ & & & & & & \\
\hline Lecythophora & & $\sqrt{ }$ & & & & $\sqrt{ }$ & \\
\hline Metschnikowia & & $\sqrt{ }$ & $\sqrt{ }$ & & & & \\
\hline Myxozyma & $\sqrt{ }$ & & & & & & \\
\hline Pichia & $\sqrt{ }$ & $\sqrt{ }$ & & & & $\sqrt{ }$ & $\sqrt{ }$ \\
\hline Pseudozyma & $\sqrt{ }$ & $\sqrt{ }$ & $\sqrt{ }$ & $\sqrt{ }$ & $\sqrt{ }$ & & \\
\hline Rhodosporidium & $\sqrt{ }$ & $\sqrt{ }$ & $\sqrt{ }$ & & & & \\
\hline Rhodotorula & $\sqrt{ }$ & $\sqrt{ }$ & $\sqrt{ }$ & $\sqrt{ }$ & $\sqrt{ }$ & & \\
\hline Spathaspora & & $\sqrt{ }$ & & & & & \\
\hline Sporidiobolus & $\sqrt{ }$ & $\sqrt{ }$ & & $\sqrt{ }$ & $\sqrt{ }$ & $\sqrt{ }$ & $\sqrt{ }$ \\
\hline Sporisorium & $\sqrt{ }$ & & & & & & \\
\hline Sporobolomyces & $\sqrt{ }$ & $\sqrt{ }$ & & & & & \\
\hline Tetrapisispora & & $\sqrt{ }$ & & & & & \\
\hline Trichosporon & $\sqrt{ }$ & & & & & & \\
\hline Ustilago & $\sqrt{ }$ & $\sqrt{ }$ & & & $\sqrt{ }$ & & \\
\hline Williopsis & & $\sqrt{ }$ & & & & & \\
\hline
\end{tabular}

region. It was first found in Indonesia by Ruinen in (1963), then it was also isolated in Thailand but not in the temperate zone (Nakase et al.2006).

It seems that the distribution of yeasts was effected by the local climate and geography of the location. The occurrence of the genera of yeasts and yeast-like fungi at different sampling sites is shown in Table 6. Kutai (Kalimantan) which has rain forest and high humidity harbors the highest number of genera (15 genera). We found that the yeasts diversity is high in the rain forests (such as Kutai, Cibodas, Enrekang, and Pucak) or the locations with high humidity (Cibinong) and tends to decrease in the forests with low humidity such as in Lombok (7 genera). Our results as shown in Table 6 indicated that there is some degree of similarity on yeasts diversity of two locations which are geographically close, for example between Cibodas and Cibinong; between Enrekang and Pucak.

Kupang which is located in Timor Island covered by savanna and dry forest harbors a unique diversity of yeasts which are differ from those of yeasts found from the rain forests in Kutai, Cibodas, Enrekang, and Pucak. Lombok which has dry climate showed some degree similarity on its yeasts diversity to those yeasts found in Kupang (Timor). The following species e.g., Cryptococcus flavescens, Cryptococcus sp., Cystofilobasidium spp., Pichia stipitis, Rhodosporidium kratochvilovae, $R$. paludigenum, and Sporobolomyces sp. were found both in Kupang and Lombok. We suggest the similarity on yeasts diversity between Kupang and Lombok because these two locations have dry climate. The presence or absence of capsules on 


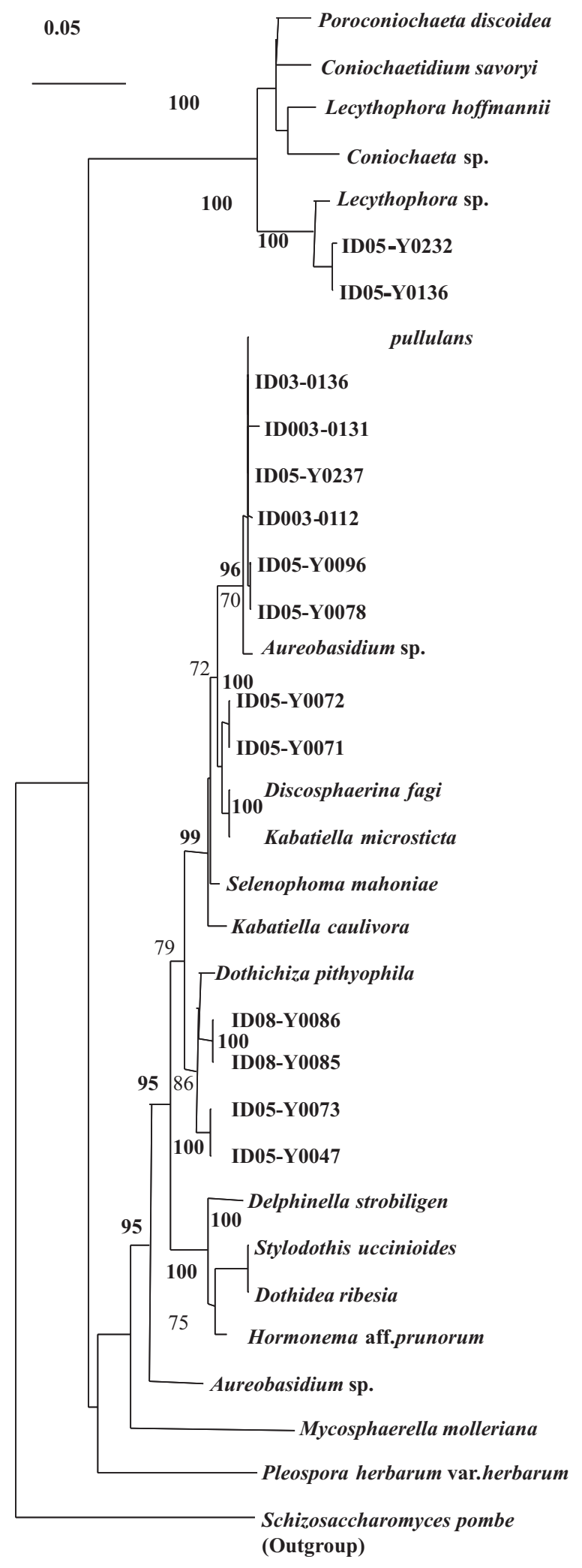

Fig 2 Phylogenetic placement of Indonesian isolates within the Euascomycetes lineage based on D1/D2 of LSU rDNA sequences.

yeast species, especially in the arid and semiarid types, may influence the ability of the yeast cells to survive in low moisture conditions (Spencer and Spencer 1997). Cryptococcus, Rhodosporidium, and Sporobolomyces are among the yeasts genera which have multi layer of cell wall and cells with capsules. Among those yeasts found in

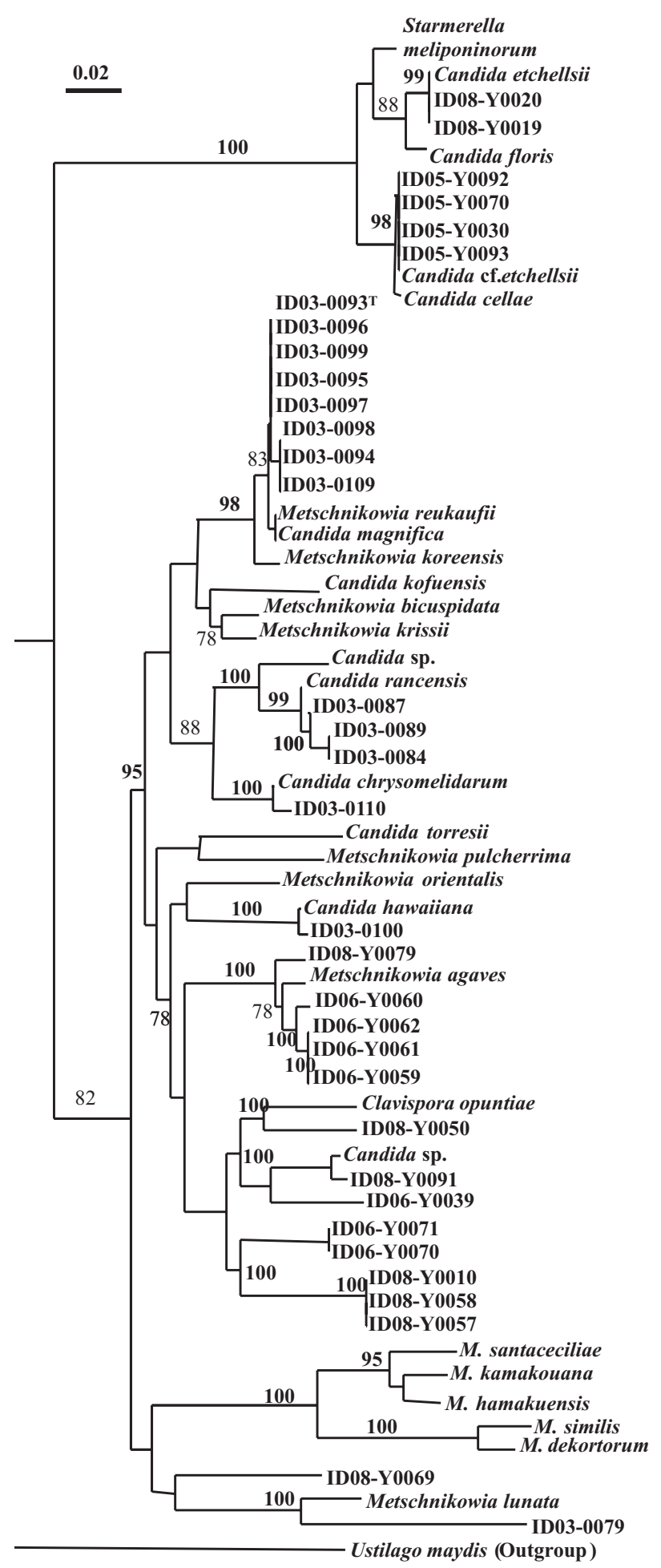

Fig 3 The phylogenetic placement of Indonesian isolates within Metschnikowiaceae lineage in the class Hemiascomycetes based on D1/D2 of LSU rDNA sequences.

this study, Cystofilobasidium was only found and common in Kupang and Lombok. The genus Cystofilobasidium has a thick-wall of teliospores (teleomorphic state) and multi layered of cell wall, these are suitable characters for yeasts to survive in dry forests.

The characteristics of substrate (physico-chemical properties) as a habitat, the intrinsic abilities (physiology) of yeasts, and the interactions within the substrate's microbial community will determine the population density and the 


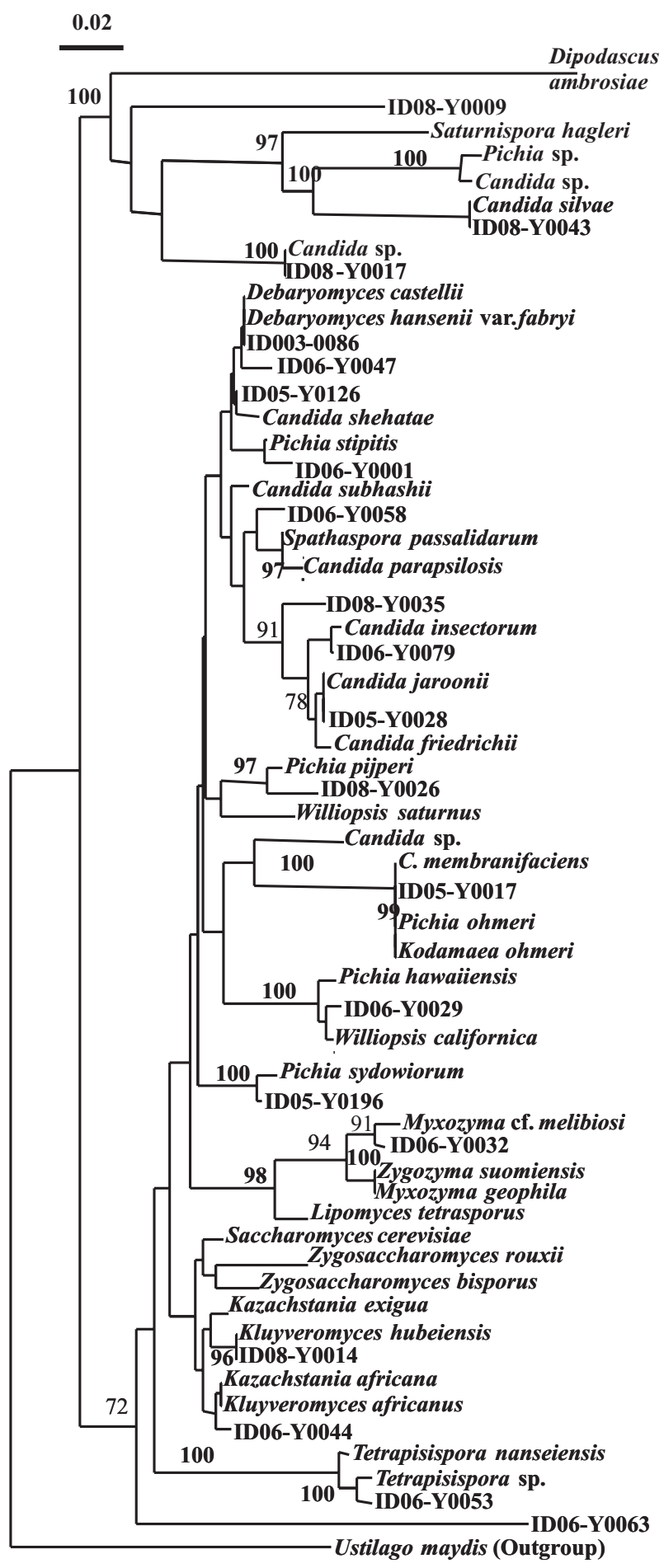

Fig 4 The phylogenetic placement of Indonesian isolates within other lineages in the class Hemiascomycetes based on D1/D2 of LSU rDNA sequences.

diversity of yeasts live in that substrate. The yeasts microflora of soils depends on the type of nutrients reaching them. Some yeasts are permanent residents in the soil and some are transients, residing temporarily in the soil. Based on the substrates, litter had the highest yeasts genera (19) followed by soil (18), flower (10), pollen (6), leaves (6), epiphytic soil (4), and insect and insect's nests (4). Genera found on soil were also common on litter. Our study showed that yeasts genera found on flower and epiphytic soil were

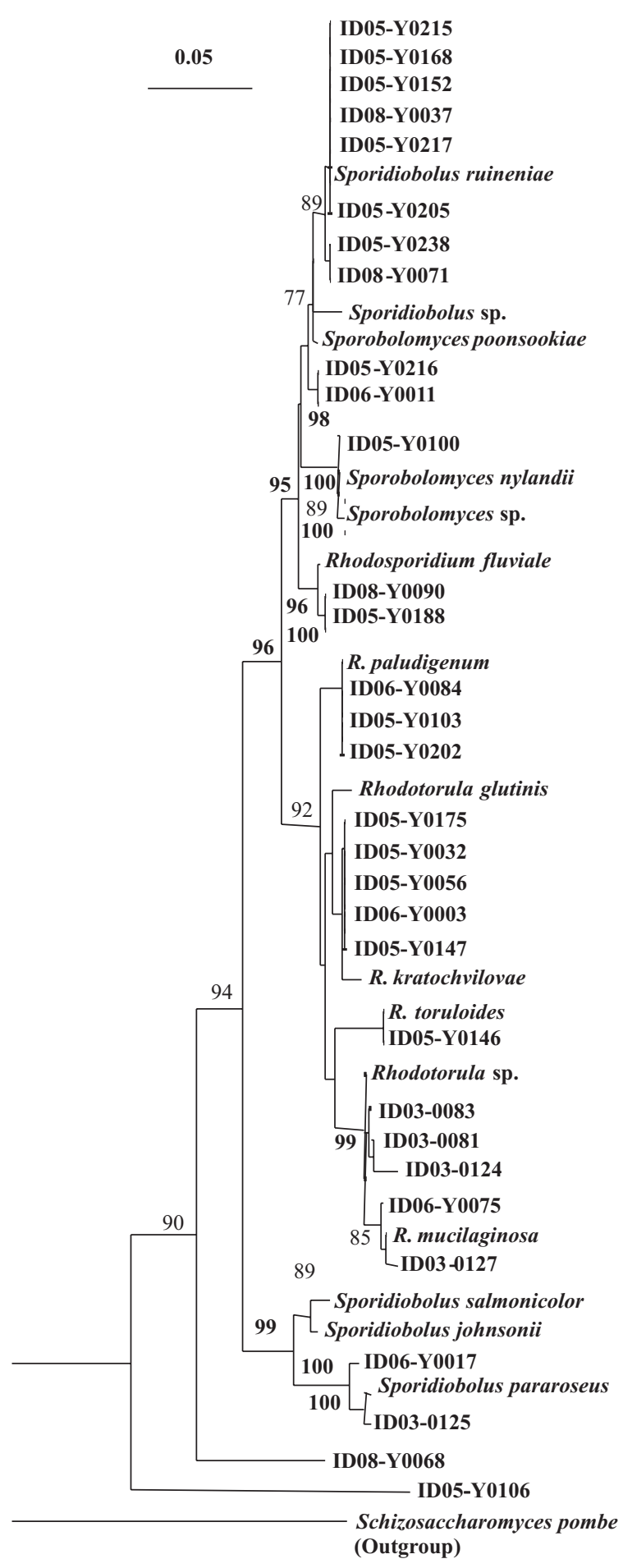

Fig 5 The phylogenetic placement of Indonesian isolates within the class Urediniomycetes as inferred from D1/D2 of LSU rDNA sequences.

common on leaves and litter. The genera Aureobasidium, Cryptococcus, Pseudozyma, Rhodotorula, and Sporidiobolus were found in all kind of substrates.

Plant surfaces have been recognized as an important habitat for yeasts. Jager et al. (2001) reported that saprophytic yeasts are common on the surfaces of leaves with the most common genera being Candida, Cryptococcus, Pichia, Rhodotorula, and Trichosporon. The yeast species Aureobasidium pullulans is common in senescent leaves (litter) and in soil (Sampaio et al. 2004). 


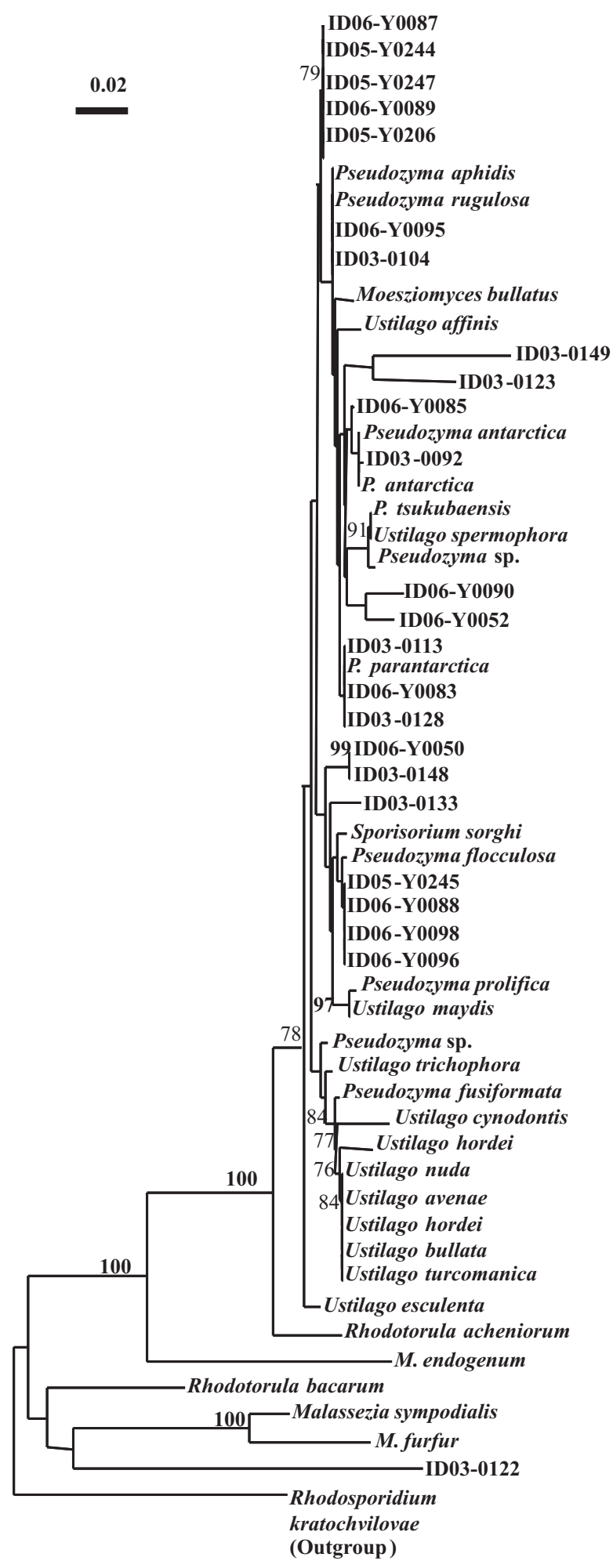

Fig 6 The phylogenetic placement of Indonesian isolates within the class Ustilaginomycetes as inferred from D1/D2 of LSU rDNA sequences.

Most flowers provide two distinct habitats for yeast. The outer surfaces and the inside of the flower near the opening harbor a yeast population similar to that of leaf and stem surfaces (i.e., Sporobolomyces, Rhodotorula, Cryptococcus, Trichosporon, and Aureobasidium). The nectaries, containing nectar of a high sugar content but low in nitrogen, have a different yeast population such as Candida and

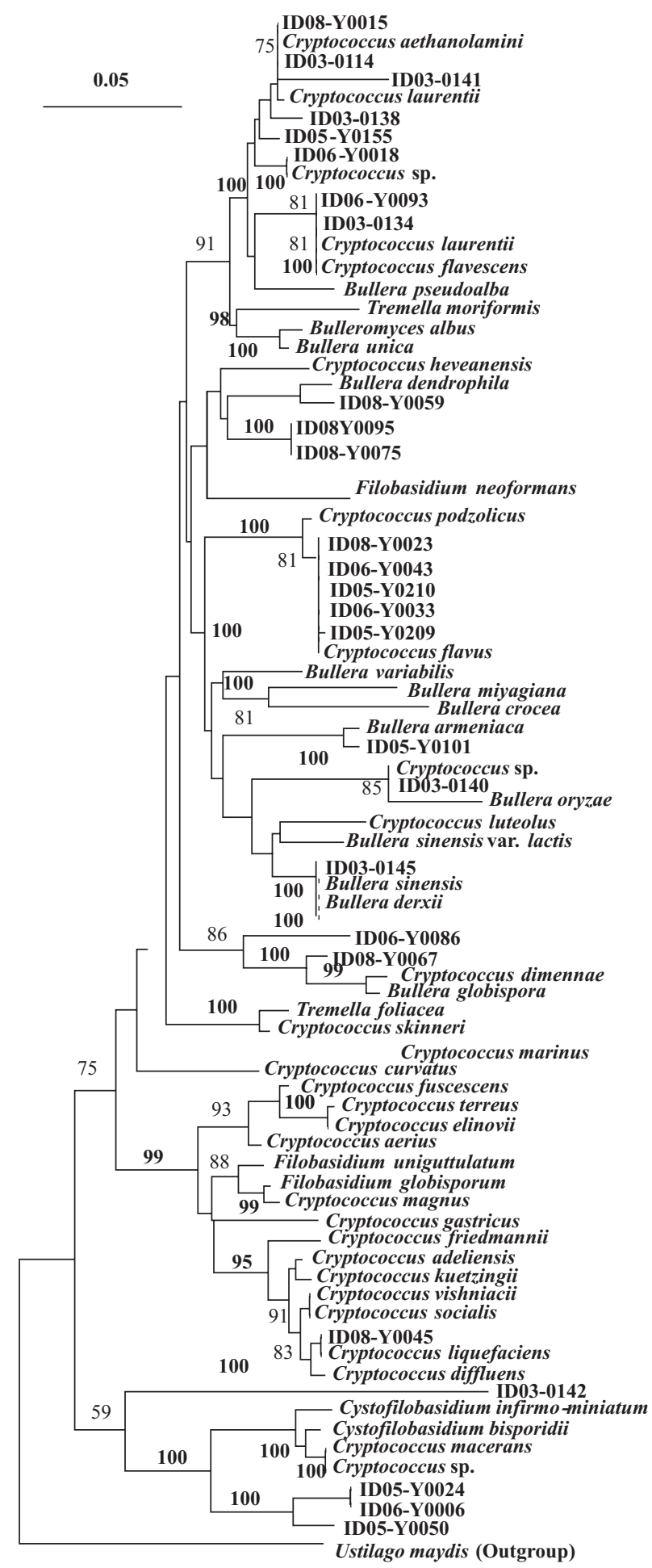

Fig 7 The phylogenetic placement of Indonesian isolates within the class Hymenomycetes, as inferred from D1/D2 of LSU rDNA sequences.

Metschnikowia, which are fermentative yeasts (Spencer and Spencer 1997; Lachance et al. 2001a).

The relationships between yeasts and insects are well established (Lachance et al. 2001a, b). Yeasts have been isolated frequently from the gut or surface of insects that feed on a variety of materials, including basidiomycete fruiting bodies, woody substrates, ephemeral flowers and nectar exudates (Lachance et al. 2001a, b; Suh and Blackwell 2004; Nguyen et al. 2007; Nakase et al. 2009). Yeasts have 
an important role in the food chain in insects. Insects not only feed on the substrates known to serve as yeast habitats, but use yeast as food source (Lachance et al. 2001b; Lachance and Bowles 2002). Yeasts convert simple nitrogenous compounds into proteins and other nutrients beneficial to insects (Sampaio et al. 2004). Suh et al. (2005) found host specialization among some of the associated insects and yeasts indicated a significant interaction between the organisms.

Epiphytic soil is an interesting habitat which has specific yeast diversity and the information of yeast diversity on this type of habitat is still limited. This study is the first contribution to the knowledge of diversity of yeasts from arthropods and epiphytic soils in Indonesia. We found some interesting taxa from insects and insect's nests (arthropods), and epiphytic soils from Kupang. We need further studies for exploration more samples of arthropods and epiphytic soils, and further study to elucidate the identity of new taxa.

Our study shed a light to detection of many undescribed yeasts from Indonesia. Molecular identification was conducted for those 515 isolates. The results based on D1/D2 region of LSU rDNA showed that 209 isolates with D1/D2 homology values less than $99 \%$, and the results based on sequence of ITS regions of those 209 isolates confirmed that they are separate species. Sequence analysis based on D1/D2 of LSU and ITS regions data detected that 209 strains from the total of 515 strains (41\%) represented new taxa. Further studies are needed to elucidate the identity of novel taxa found in this study. Yeasts have always been blind spot for biodiversity studies in Indonesia. Our study has broadened our knowledge on Indonesian biodiversity. This study has very important implication on our knowledge of estimates of yeasts diversity in tropical forests in Indonesia and provides some insights into the distribution of yeasts on different substrates and ecosystems in Indonesia.

\section{ACKNOWLEDGEMENT}

This work was conducted collaboratively between the Indonesian Institute of Sciences (LIPI), representing the Government Research Centers of the Republic of Indonesia and the National Institute of Technology and Evaluation (NITE) Japan. We thank Keiichiro Okuda, Kenji Tanaka, Takashi Nakase, Shigeaki Harayama, Ken-Ichiro Suzuki, Kozaburo Mikata, Toshikazu Sakamoto, Yumi Imanishi, Hiroko Kawasaki, Yuko Kurihara, Ju-Young Park, Shigeki Inaba, Shinya Ninomiya, Kozue Anzai, Tomoaki Kamijyo, and Rieko Suzuki (NITE) for their valuable discussions and helps. We also thank Rahmat, Rahmat Fauzi, Fitrianingsih, and Yeni Yuliani for their helps on yeasts isolation and characterization.

\section{REFERENCES}

Alikodra HS, Syaukani HR. 2004. Bumi makin panas banjir makin luas, menyibak tragediy kehancuran hutan. Bandung: Nuansa.

Altschul SF, Thomas LM, Schaffer AA, Zhang J, Zhang Z, Miller W, Lipman DJ. 1997. Gapped BLAST and PSI-BLAST: a new generation of protein database search programs. Nucleic Acids Res 25:3389-402.
Caligiorne RB, Licinio P, Dupont J, de Hoog GS. 2005. Internal transcribed spacer rRNA gene-based phylogenetic reconstruction using algorithms with local and global sequence alignment for black yeasts and their relatives. J Clin Microbiol:2816-823.

Felsenstein J. 1985. Confidence limits on phylogenies: an approach using the bootstrap. Evolution 39:783-91.

Haryono B, Hamamoto M, Kuswanto KR, Nakase T. 1999. Systematics of ballistoconidium-forming yeats equipped with $\mathrm{Q}-10\left(\mathrm{H}_{2}\right)$ as major ubiquinone isolated from plants in Indonesia. In: Int Conf Asian Network on Microbial Research, Nov, Chiang Mai, Thailand. p 85461. Chiang Mai:ANMR.

Hawksworth DL. 1991. The fungal dimension of biodiversity: magnitude, significance, and conservation. Mycol Res 98: 641-55.

Hawksworth DL. 2002. Why study tropical fungi? Tropical mycology Vol 2. Micromycetes. Watling R, Frankland JC, Ainsworth AM, Isaac S, Robinson CH, editors. CAB International 2002:1-11.

Jager ES, Wehner FC, Korsten L. 2001. Microbial ecology of the mango phylloplane. Microb Ecol 42:201-7.

Kimura M. 1980. A simple method for estimating evolutionary rate of base substitutions through comparative studies of nucleotide sequences. J Mol Evol 16:111-20.

Kurtzman CP, Robnett CJ. 1998. Identification and phylogeny of ascomycetous yeasts from analysis of nuclear large subunit (26S) ribosomal DNA partial sequences. Antonie Leeuwenhoek 73:331-71.

Lachance MA, Bowles JM. 2002. Metschnikowia arizonensis and Metschnikowia dekortorum, two new large-spored yeast species associated with floricolous beetles. FEMS Yeast Res 2:81-6.

Lachance MA, Bowles JM, Kwon S, Marinoni G, Starmer WT, Janzen DH. 2001a. Metschnikowia lochheadii and Metschnikowia drosophilae, two new yeast species isolated from insects associated with flowers. Can J Microbiol 47:103-9.

Lachance MA, Starmer WT, Rosa CA, Bowles JM, Barker JSF, Janzen, DH. 2001b. Biogeography of the yeasts of ephemeral flowers and their insects. FEMS Yeast Res 1:1-8.

Nakase T, Jindamorakot S, Am-In S, Potacharoen W, Tanticharoen M. 2006. Yeast biodiversity in tropical forests of Asia. In: Rosa C, Peter $\mathrm{G}$, editors. Biodiversity and ecophysiology of yeasts. Berlin Heidelberg: Springer-Verlag. p 441-60.

Nakase T, Jindamorakot S, Ninomiya S, Imanishi Y, Kawasaki H. 2009. Candida wancherniae sp. nov. and Candida morakotiae sp. nov., two novel ascomycetous anamorphic yeast species found in Thailand. J Gen Appl Microbiol 55:93-100.

Nguyen NH, Suh SO, Blackwell M. 2007. Five novel Candida species in insect-associated yeast clades isolated from Neuroptera and other insects. Mycologia 99:842-58.

Oetari A, Gandjar I, Lindah. 1999. Yeasts isolated from various banana fruits of Indonesia. In: Proceeding of the international conference Asian network on microbial research; 1999 Nov 29-Dec 1; Chiang Mai, Thailand.p 105-14. Chiang Mai:ANMR.

Ruinen J. 1963. The phyllosphere II. Yeasts from the phyllosphere of tropical foliage. Antonie Leeuwenhoek 29: 425-38.

Saitou N, Nei M. 1987. The neighbor-joining method: a new method for reconstructing phylogenetic trees. Mol Biol Evol 4:406-25.

Sampaio A, Cortes R, Leão C. 2004. Yeast and macroinvertebrate communities associated with leaf litter decomposition in a second order stream. Internat Rev Hydrobiol 89: 453-66.

Sjamsuridzal W, Gandjar I. 1994. Isolation and characterization of yeasts isolated from overripe fruits in Jakarta and vicinities. UNESCO Southeast Asia regional training workshop: rapid methods in microbiology and biotechnology, Oct, Bangkok. p 1-7. Bangkok: Kasetsart Univ.

Sjamsuridzal W, Oetari A. 2003. Rapid preparation of fungal and bacterial genomic DNA for PCR. Hayati 10:122-4.

Spencer JFT, Spencer DM. 1997. Ecology: where yeasts live. In: Spencer JFT, Spencer DM, editors. 1997. Yeasts in natural and artificial habitats. Berlin: Springer-Verlag. p 33-58.

Sugita T, Nishikawa A, Ikeda R, Shinoda T. 1999. Identification of medically relevant Trichosporon species based on sequences of internal transcribed spacer regions and construction of a database for Trichosporon identification. J Clin Microbiol 37:1985-93.

Suh SO, Blackwell M. 2004. Three new beetle-associated yeast species in the Pichia guilliermondii clade. FEMS Yeast Res 5:87-95. 
Suh SO, McHugh JV, Pollock DD, Blackwell M. 2005. The beetle gut: a hyperdiverse source of novel yeasts. Mycol Res 109:261-5.

Thompson JD, Higgins DG, Gibson TJ. 1994. CLUSTAL W: improving the sensitivity of progressive multiple sequence alignment through sequence weighting, position-specific gap penalties and weight matrix choice. Nucleic Acids Res 22:4673-80.
White TJ, Bruns T, Lee S, Taylor J. 1990. Amplification and direct sequencing of fungal ribosomal RNA genes for phylogenetics. In: Innis MA, Gelfand DH, Sninsky JJ, White TJ, editors. PCR protocols: guide to methods and applications. San Diego: Academic Pr. p315-22.

Yarrow D. 1998. Methods for the isolation, maintenance and identification of yeasts. In : The yeasts, a taxonomic study, $4^{\text {th }}$ ed, Kurtzman CP, Fell JW, editors. Amsterdam: Elsevier. p 77-100. 